\title{
ANALYSIS FINANCIAL SERVICES COOPERATION AND THE FACTORS AFFECTING IT VIEWED FROM CUSTOMER PERSPECTIVES
}

\author{
Yurniwati $^{1 *}$, Zuli Falida Folza ${ }^{2}$, Yessel Pissi ${ }^{3}$ \\ Andalas University Faculty of Economics ${ }^{123}$ \\ yurniwati.fekon.unand@gmail.com ${ }^{l)}$ zulifalidafloza@gmail.com ${ }^{21}$ yesselpissi@gmail.com ${ }^{3)}$
}

\begin{abstract}
Sharia Financial Services Cooperative (KJKS) is a cooperative whose business activities are engaged in financing, investment, and savings under the profit-sharing pattern (sharia). However, the funding provided by KJKS currently has a high risk, thus disrupting the performance of KJKS. The purpose of this study was to analyze the financing of problems in KJKS in the city of Padang. The study was conducted on inefficient KJKS obtained from KJKS which had the lowest increasing return to scale and decreasing return to scale values. The variables studied were non-performing financing (NPF) as the dependent variable and religiosity, financing planning, revenue sharing, initial administration requirements, and KJKS evaluation as an independent variable. The method of analysis uses descriptive analysis and hypothesis test analysis. The results showed the average level of non-performing financing (NPF) KJKS is at high risk, KJKS which has an NPF value above 5\% as required by Bank Indonesia. But there are KJKS whose NPF has decreased every year such as the Parak Rumbio and Surau Gadang, Batu Gadang, Ampang, Kurau Pagang domains. Description of the variable of religiosity found the respondents have a good intention to pay the installment financing. The results of hypothesis testing prove that customer religiosity has a significant effect on problem financing. Financing planning does not affect problem financing. Customer income has a significant effect on problem financing. The initial administrative factor does not affect problem financing. The evaluation factor by the KJKS does not affect problem financing.
\end{abstract}

Keyword: Problem Funding; Religiosity; Funding Planning; KJKS

*Corresponding author

Email: yurniwati.fekon.unand@gmail.com

DOI: https://doi.org/10.33369/j.akuntansi.10.3.275-286

\section{INTRODUCTION}

Currently, Islamic financial institutions are experiencing rapid development. This can be proven by the increase in total sharia financial assets in the last 4 years to reach Rp.306 trillion or equivalent to $4.8 \%$ of total national banking assets. As of June 2016, there were 12 sharia commercial banks, 22 Sharia Business Units (UUS), and 165 Sharia Rural Banks in 2,557 branch offices throughout Indonesia (www.bi.go.id/, accessed February 5, 2017). On a microscale this was also followed by the development of the Sharia Microfinance Institution (LKMS), the only thing that is of concern is the Islamic Financial Services Cooperative (KJKS), (infobanknews.com, 2017).

KJKS is a cooperative whose business activities are engaged in financing, investment, and savings under the profit-sharing pattern (Syariah), (Kepmen, 2004). The purpose of establishing KJKS according to the Republic of Indonesia Minister for Cooperatives and SMEs Regulation No. 35.3 / Per / M.KUKM / X / 2007, including increasing economic empowerment programs, especially among Micro, Small and Medium Enterprises (MSMEs) and cooperatives through the sharia system, encouraging sharia economic life in micro, small and medium business activities in particular and the Indonesian economy in general and increase the enthusiasm and participation of community members in KJKS activities.

KJKS business through the financing provided has a great risk. Financing is the provision of loans to meet the needs of those who lack funds both for productive needs (business improvement) and for consumptive needs (Ayuningtiyas, 2012). In financing, there is an 
element of risk, namely uncertainty in the return of financing. This is what is known as bad credit or non-performing financing (Non-Performing Financing / NPF). Not a few Islamic financial institutions went bankrupt due to the problem of bad credit (Abdulkader, 2013).

The history of the presence of KJKS in the city of Padang began in 2010 with the realization of the Urban Micro Credit (KMK) budget through the Baitul Maal Wat Tamwil Sharia Financial Services Cooperative (KJKS-BMT) by the Padang city government. At that time the Padang City Government realized the KMK budget through KJKS BMT in 54 villages, with each village receiving a fund of Rp. 300,000,000. The total amount of funds channeled to

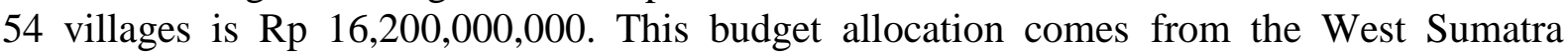
Province Regional Budget and Padang City. The year 2011 are-establishing 20 KJKS and in 2012 continued with the establishment of $30 \mathrm{KJKS}$ so that a total of $104 \mathrm{KJKS}$ were spread across 11 sub-districts of Padang City (Novitasari, 2010).

Problematic financing will hurt KJKS, both financially and non-financially (Maulidia, 2016). Financial losses include not meeting revenue targets, disruption of cash flow, and reducing capital because the costs are greater than income. While non-financial losses include declining performance and soundness of KJKS.The KJKS and the customer before entering into a financing transaction always agree with between the two parties, which is stated in a financing agreement. Thus both are bound by agreements and laws that have been made together. In essence, sometimes there are breaches of promises made by members who do not carry out their obligations to the relevant KJKS, which had previously been a joint agreement between the two, both intentional and unintentional (Listanti, 2015). Non-Performing Financing (NPF) is a ratio used to measure the ability of an institution to cover the risk of failure to repay loans by debtors. NPF reflects credit risk, the higher the NPF level, the higher the credit risk borne by the bank (Marantika, 2013). NPF ratio is the ratio used to measure the risk of failure from financing, where NPF is the ratio between non-performing financing (which is included in the criteria for substandard, doubtful, and loss) and the total financing channeled (Maulidia, 2016).

Bank Indonesia regulations regarding safe NPF levels are not more than 5\%. This provision indicates that the banking business can continue to run even increase if the bank as an intermediary institution can manage credit products by adhering to the principle of prudence (Dendawijaya, 2005). Similar to Islamic banking, KJKS can also be measured by the quality of its financing from the NPF ratio. The higher this ratio, shows that the quality of financing is increasingly unhealthy (Wijayanti, 2014).

What are the factors that cause high problem financing? Factors affecting NPF can be seen from the side of customers (debtors), financial institutions (creditors), and other external (external) factors. Several studies have been conducted to analyze the factors that affect NPF. Siregar (2013), research on the character of Sharia Bank debtors in fulfilling obligations found that decreasing the amount of problem financing in BPRS with a strong religious, persistence, and pressure approach, gave positive results on resolving customer obligations. In Siregar (2013) study, religiosity and economic behavior are linked based on research by German political economist and sociologist (Weber, 1905). In his book, The Protestant Ethic and the Spirit of Capitalism, explains that modern capitalism developed in Western Europe and America thanks to this Protestant ethic. The Protestant Reformation (Calvinism), has given birth to fundamentally new values, which provide the impetus for businesses that activate the economy. The results of this study indicate. In financing, religiosity concerns the issue of how customers apply Islamic law which will have an impact on their intentions. Results of research conducted by Novitasari (2010; Harmoyo (2012; Wijayanti (2014); Yuliana (2016) shows that customer intentions have a significant effect on NPF. 
However, Ayuningtiyas (2012) found that intention did not affect NPF. This gives impetus to businesses that activate the economy. The results of this study indicate. In financing, religiosity concerns the issue of how customers apply Islamic law which will have an impact on their intentions. Results of research conducted by Novitasari (2010; Wijayanti (2014; Yuliana (2016) shows that customer intentions have a significant effect on NPF. However, Ayuningtiyas (2012) found that intention had no effect on NPF. which gives impetus to businesses that activate the economy. The results of this study indicate. In financing, religiosity concerns the issue of how customers apply Islamic law which will have an impact on their intentions. Their research shows that customer intentions have a significant effect on NPF. However, (Ayuningtiyas, 2012) found that intention did not affect NPF. Yuliana (2016) shows that customer intentions have a significant effect on NPF. However, Ayuningtiyas (2012) found that intention did not affect NPF. Yuliana (2016) shows that customer intentions have a significant effect on NPF. However, Yuliana (2016) found that intention did not affect NPF.

Previous research that also examined the problematic financing was carried out by Ayuningtiyas (2012; Wijayanti (2014) who found that financial planning did not affect the NPF. Other variables found by previous researchers that affect NPF are customer income (Novitasari, 2010). The initial requirements administration factor (Ayuningtiyas, 2012; Wijayanti, 2014) and evaluation by the KJKS (Listanti, 2015) which were also previously examined showed no effect on NPF.

The relationship between religiosity illustrates the relevance between the teachings of Islam as stipulated in the Qur'an and Sunnah about the need to hurry up paying debt obligations. This is what is practiced by Muslims when paying their obligations to the financial institutions concerned. KJKS is a financial institution that uses Islamic approaches so that it can encourage customers to have a better intention from forming to completing financing. But in reality, KJKS still often has a high NPF (Siregar, April 2013).

Financing planning is the first step in designing a strategy that is carried out by the customer in managing loan funds. This can give an idea to the KJKS that the financing provided can be managed following the plan, while the customer making plans related to the use of loan funds will facilitate the customer in returning the loan funds. However, in reality, this initial planning is often not under its objectives. Customers as debtors who obtain financing from KJKS must repay loans received by the agreement made. Then the customer's income is an important element so that the obligation to pay for the financing obtained can be fulfilled.

Financing administration includes activities in the form of gathering information, presenting data, recording, mastering documents related to the process of financing activities by related work units in the implementation of sound financing management. When applying for a loan, a client is required to fulfill the loan application requirements set by the agency that provided the loan. Any financial institution in the form of a bank or a sharia financial institution such as KJKS must-have requirements when lending to customers. Requirements that have been met can be considered in providing financing.

Evaluation is an assessment process. In financing, evaluation can be interpreted as a process of measuring the effectiveness of the financing stages from the establishment to completion. Cooperatives as financial institutions that provide financing can conduct evaluations such as following up on customers who have not paid installments on the financing obtained and monitor the effectiveness of funds utilized by customers. The evaluation conducted by the cooperative is expected to help the customer to control during the loan period. Each customer has a different character in assessing whether an evaluation conducted by a cooperative has a positive or negative impact on its financing.

Research on problematic financing (NPF) in KJKS in Padang city, is an interesting actual phenomenon to be observed, one of which is the factors that influence from the customer's perspective. Husni (2016) found that only $14 \mathrm{KJKS}$ were efficient. The assessment 
uses Data Envelopment Analysis (DEA) based on a return to scale analysis. Cooperative will have one of the conditions of return to scale, namely the Increasing Return To Scale (IRS), Constant Return To Scale (CRS), or Decreasing Return To Scale (DRS) (Siswandi, 2004; Wira, 2015). KJKS is said to be efficient if it has a CRS value equal to 1 (one). In this study, it will be examined How is the level of NPF on KJKS inefficient, and is there a difference in the level of NPF on KJKS that tends to be efficient and inefficient? How does the influence of customer religiosity, financial planning, customer income, administration initial requirements, and evaluation of KJKS on problem financing?

Research on problematic financing in the city of Padang was conducted at KJKS categorized inefficiencies which can be grouped as increasing returns to scale (IRS) or decreasing return to scale (DRS) criteria. Cooperatives with IRS criteria mean that the cooperative is inefficient but there is still hope to achieve efficiency, while cooperatives included in the DRS criteria mean the cooperative is inefficient but it is difficult to immediately reach efficiently. The author's focus is on inefficient cooperatives with DRS criteria at $5 \mathrm{KJKS}$ which have the lowest scale and 5 KJKS which have the lowest IRS value.

\section{THEORETICAL FRAMEWORK AND HYPOTHESES}

\section{Islamic Financial Institutions}

According to the National Sharia Board (DSN), a sharia financial institution is an institution that issues sharia financial products and has received an operating license as a sharia financial institution (DSN-MUI, 2003). Islamic Financial Institutions carry out their activities based on Islamic sharia principles. Sharia microfinance institutions are microfinance institutions that are based on sharia operations (Maulidia, 2016). At present, thanks to the growing development of the sharia economy in Indonesia, sharia-based microfinance institutions are also increasing both in number and performance (Amri and Widyaningsih, 2016). One of the sharia financial institutions in the city of Padang is the Islamic Financial Services Cooperative (KJKS). According to the Decree of the State Minister for Cooperatives and Small and Medium Enterprises of the Republic of Indonesia Number 91 / Kep / IV / KUKM / IX / 2004, (Kepmen, 2004). KJKS is "a cooperative whose business activities are engaged in financing, investment, and savings according to profit-sharing patterns (sharia)."

\section{Financing}

According to Law No. 10 of 1998, financing is the provision of money or bills that can be equaled, based on an agreement or agreement between the bank and the party that requires the financed party to return the money or claim after a certain period with compensation or profit-sharing (Law, 1998).

\section{Non-performing Financing}

According to Bank Indonesia circular no. 9/24/DPbs year 2007 concerning the bank's health assessment system based on sharia principles, non-performing financing is financing that occurs when the debtor (mudarib) for various reasons cannot fulfill the obligation to return the financing funds (loans).

\section{Non-performing Financing Ratio}

Non-Performing Financing(NPF) is a ratio used to measure the ability of an institution to cover the risk of failure of credit repayment by the debtor. NPF reflects credit risk, the higher the NPF level, the higher the credit risk borne by the bank (Mahsyud Ali, 2008). The formula for calculating the NPF ratio is as follows: 
$\mathrm{NPF}=\frac{P B(K L+D+M)}{\text { TotalPembiayaan }} \times 100 \%$

\section{Hypothesis}

The hypothesis is an initial statement that must be tested for truth. The hypothesis arises from a review of several studies that are used as a reference for this research. Based on the previous theoretical and research studies, the following hypotheses were made:

\section{The Influence of Customer Religiosity on Non-Performing Financing}

Religiosity concerns the issue of how a customer implements Islamic law that will later have an impact on his faith in financing. The relationship between religiosity and customer intentions illustrates the relevance between the teachings of Islam as stipulated in the Qur'an and Sunnah about the need to immediately repay debt obligations with the reality practiced by Muslims when paying their obligations to the financial institutions concerned.

Customers are a type of belief, trust, or willpower. The customer's intention is related to the good intention of the customer to repay the loan that has been made based on an agreement that has been agreed with the institution that provided the funds. This customer's intention is related to the nature or character of a person. The nature or character of the prospective customer (group members) who will be given credit funds must meet the requirements specified by the lender. To find out the nature of the prospective debtor can be known from the background of prospective debtors, both work and personal. Then a customer's intention must be high to be able to fulfill his obligations to pay installments on the financing provided to him.

Research conducted by Siregar (2013) shows that the religious approach influences the $\mathrm{NPF}$ and has relevance to the customer's intention in completing its financing. The religious approach can be used as an effort to reduce the level of NPF in Islamic banks. Meanwhile, research conducted by Novitasari (2010; Wijayanti, (2014; Yuliana, (2016) showed results that customer I'tikad had a significant effect on NPF and microcredit shari'a Baitul Maal Wa Tamwil.

Referring to the research, so the hypotheses that can be developed, are:

$\mathrm{H}_{1}$ : Customer Religiosity Variable has a significant effect on Non-Performing Financing

\section{Effect of Financing Planning on Non-Performing Financing}

Financing planning is the first step in designing a strategy that is carried out by the customer in managing loan funds. This can give an idea to the KJKS that the financing provided can be managed as planned, while for the customer making plans related to the use of loan funds will facilitate the customer in returning the loan funds. But in reality, this initial planning is often not following its objectives. Research conducted by Apriliani (Ayuningtiyas, 2012; Wijayanti, 2014) shows the results that financial planning has no significant effect on nonperforming loans in the Sharia micro-finance institution Baitul Maal Wa Tamwil. Referring to the results of the two studies, the hypotheses that can be developed are:

$\mathrm{H}_{2}$ : The variable of financial planning has a significant effect on Non-Performing Financing

\section{The Influence of Customer Revenues on Non-Performing Financing}

In the big Indonesian dictionary, income is the result of work (business and so on). Customers as debtors who obtain financing from KJKS, should repay loans received under the agreement made. Then the customer's income is an important element so that the obligation to pay for the financing obtained can be fulfilled. Research conducted by Popita (2013) results of his research shows that customer income has a significant effect on NPF seen from the perspective of financing partners on BMT, so the hypotheses that can be developed are: 
$\mathrm{H}_{3}$ : Customer income variable significantly influences the Non-Performing Financing

\section{Effect of Administrative Prerequisites on Non-Performing Financing}

In granting financing to customers, it is necessary to have terms and agreements between the parties that provide financing and those who receive financing or better known as customers. Financing requirements forKJKS must be arranged and implemented properly so as not to complicate and benefit both parties. Ayuningtiyas (2012); Popita (2013); Wijayanti (2014) examined the effect of the initial administrative requirements on non-performing financing and bad credit on BMTs. The study showed no significant effect between the administration of the initial requirements with non-performing financing and bad credit on BMT. So, the hypothesis that can be developed is:

$\mathrm{H}_{4}$ : Initial requirements administrative variables have a significant effect on Non-Performing Financing

\section{The Influence of Evaluation by the Sharia Financial Services Cooperative on Non-Performing Financing}

In financing, evaluation can be interpreted as a process of measuring the effectiveness of the financing stages from the establishment to completion. KJKS as a financial institution that provides financing can conduct evaluations such as following up on customers who have not paid installments on the financing obtained. The evaluation conducted by the cooperative is expected to help the customer to control financing during the loan period. Each customer has a different view in assessing whether evaluations conducted by cooperatives have a positive or negative impact on their financing. Based on research conducted by Popita (2013), the results show that evaluation does not significantly influence the problematic financing and nonperforming loans of the Islamic microfinance institutions Baitul Maal Wa Tamwil,

$\mathrm{H}_{5}$ : The evaluation variable by the KJKS has a significant effect on Non-Performing Financing

\section{Research design}

\section{METHODS}

This research is descriptive verification research that describes the relationship between the independent variable and the dependent variable. The unit of analysis examined is a dyad that consists of organizations namely KJKS and individuals, namely customers. The level of researcher intervention in this study is minimal because the researcher only studies events as they are, without manipulating and/or controlling and simulating. Time horizon, this research was carried out once (one-shot).

\section{Variables and Measurements}

The dependent variable (bound) in this study is non-performing financing (NPF). Indicator NPF variable is the cause of customer incapability in financing. The independent variables in this study include Problem Funding; Religiosity; Funding Planning.

Table 1. Variable Operations

\begin{tabular}{cll}
\hline No & \multicolumn{1}{c}{ Variable } & \multicolumn{2}{c}{ Indicator } \\
\hline 1 & $\begin{array}{l}\text { Customer } \\
\text { Religiosity }\end{array}$ & $\begin{array}{l}\text { Implementation of Islamic Sharia, Customs, Determination, Customer } \\
\text { Intentions }\end{array}$ \\
\hline 2 & $\begin{array}{l}\text { Financing } \\
\text { Planning }\end{array}$ & The submission process, Realization of Planning, Planning Function \\
\hline 3 & $\begin{array}{l}\text { Customer } \\
\text { Revenue }\end{array}$ & Benefits, the ability to pay off \\
\hline 280 & &
\end{tabular}




\begin{tabular}{cll}
\hline No & \multicolumn{1}{c}{ Variable } & \multicolumn{1}{c}{ Indicator } \\
\hline 4 & $\begin{array}{l}\text { Initial } \\
\text { Administration } \\
\text { Requirements }\end{array}$ & $\begin{array}{l}\text { Convenience when applying for financing, Excellence when applying for } \\
\text { financing }\end{array}$ \\
\hline 5 & $\begin{array}{l}\text { Evaluation by } \\
\text { KJKS }\end{array}$ & $\begin{array}{l}\text { Customer evaluation regarding the service and performance of KJKS } \\
\text { employees }\end{array}$ \\
\hline Source: & Author Processed, 2017.
\end{tabular}

\section{Data and Data Collection Methods}

The data used in this study consisted of primary data and secondary data. Primary data were obtained through a questionnaire aimed at KJKS customers. Secondary data used in this study are efficiency data KJKS in Padang based on Decreasing Return to Scale (DRS), KFKS NPF report in Padang in 2014-2016. Data collection methods used in this research are field studies and literature studies. The field study used a questionnaire that was made in the multiplechoice category using a Likert scale because the researcher wanted to find out the influence of customer factors on the NPF on KJKS in Padang City.

\section{Population and Sample}

The population of this study is for KJKS are all Islamic Financial Services Cooperatives (KJKS) in the city of Padang. The sampling technique is purposive sampling, which is a sampling method based on certain criteria established by researchers (Sekaran, 2006). The criteria set are Cooperatives based on the DEA efficiency measurement method with a return to scale analysis including those with inefficiency with decreasing return to scale (DRS) criteria at $5 \mathrm{KJKS}$ having the lowest scale and $5 \mathrm{KJKS}$ with the lowest increasing return to scale (IRS). While the sample collection method for customers is Simple Random sampling is a random sampling technique without certain considerations (Sugiyono, 2013). The customers selected from 5 KJKS that have been determined are chosen randomly.

\section{Analysis Method}

1) Descriptive Analysis of Percentages

2) Hypothesis test: Statistical Test F (Simultaneous Test) and Statistical Test t (Partial Test)

\section{RESULT AND DISCUSSION}

\section{Development of KJKS NPF Ratio in Padang City in 2014-2016}

The following are the average KFKS NPF levels in 11 districts in Padang during 20142016:

Table 2. KJKS NPF Level by Subdistrict in Padang

\begin{tabular}{clccc}
\hline No & sub-district & 2014 & 2015 & 2016 \\
\hline 1 & Lubuk Begalung & $21.18 \%$ & $22.48 \%$ & $19.61 \%$ \\
\hline 2 & South Padang & $30.81 \%$ & $30.10 \%$ & $31.36 \%$ \\
\hline 3 & West Padang & $13.29 \%$ & $14.11 \%$ & $12.78 \%$ \\
\hline 4 & East Padang & $27.66 \%$ & $32.63 \%$ & $28.22 \%$ \\
\hline 5 & Kuranji & $10.80 \%$ & $10.94 \%$ & $10.06 \%$ \\
\hline 6 & Lubuk Kilang & $9.38 \%$ & $3.50 \%$ & $2.23 \%$ \\
\hline 7 & North Padang & $18.98 \%$ & $15.32 \%$ & $13.35 \%$ \\
\hline 8 & Pauh & $9.82 \%$ & $7.72 \%$ & $7.95 \%$ \\
\hline 9 & Nanggalo & $7.58 \%$ & $8.32 \%$ & $7.30 \%$ \\
\hline 10 & Koto Tangah & $14.59 \%$ & $14.79 \%$ & $17.61 \%$ \\
\hline 11 & Bungus Teluk Kabung & $35.80 \%$ & $28.41 \%$ & $27.52 \%$ \\
\hline & Average & $19.35 \%$ & $19.40 \%$ & $17.63 \%$ \\
\hline
\end{tabular}

Source: Author Processed, 2017. 
Based on the table, the average NPF of KJKS in Padang City grouped into 11 subdistricts was in the NPF level which was very risky or not good, namely, for 2014 the average NPF rate was $19.35 \%$, in 2015 it was $19.40 \%$, and in 2016 experienced a decrease of $17.63 \%$. This is based on the guidelines for the maximum gross NPF level issued by Bank Indonesia, which is a maximum of only $5 \%$ as a tolerant figure for the health of an LKS. If the NPF level is above $5 \%$, then it can be concluded that the NPF on the KJKS is not good even very risky. The NPF level for KJKS that became the object of research is $10 \mathrm{KJKS}$ which has the lowest DRS and IRS values shown in the table below:

Table 3. NPF Level of Research Object

\begin{tabular}{clccc}
\hline No. & \multicolumn{1}{c}{ KJKS name } & 2014 & 2015 & 2016 \\
\hline 1 & Kubu Marapalam & $33.60 \%$ & $43.74 \%$ & $31.34 \%$ \\
\hline 2 & Back of the Cottage & $13.23 \%$ & $26.35 \%$ & $26.55 \%$ \\
\hline 3 & Surau Gadang & $9.54 \%$ & $8.45 \%$ & $6.99 \%$ \\
\hline 4 & Parak Rumbio realm & $70.52 \%$ & $30.30 \%$ & $27.61 \%$ \\
\hline 5 & Parak Gadang Timur & $52.16 \%$ & $50.01 \%$ & $64.04 \%$ \\
\hline 6 & Koto Pulai & $0.95 \%$ & $15.99 \%$ & $6.88 \%$ \\
\hline 7 & Gadang Stone & $8.70 \%$ & $0.00 \%$ & $1.97 \%$ \\
\hline 8 & Tangi Pia & - & $0.00 \%$ & $5.94 \%$ \\
\hline 9 & Ampang & $10.53 \%$ & $2.42 \%$ & $2.31 \%$ \\
\hline 10 & Kurao Intern & $7.55 \%$ & $3.77 \%$ & $4.15 \%$ \\
\hline & Average & $35.81 \%$ & $31.77 \%$ & $31.31 \%$ \\
\hline
\end{tabular}

Source: KJKS financial report (2017).

Based on the table, it can be seen that the average NPF annually fluctuates. However, if it is focused on each KJKS, there are KJKS that have NPF levels that decline each year. For example, KJKS Ampang, the NPF rate in 2014 of $10.53 \%$ decreased in 2015 to $2.42 \% \%$ then decreased again in 2016 to $2.31 \%$. KJKS Surau Gadang in 2014 had an NPF rate of $9.54 \%$, in 2015 it decreased to $8.45 \%$, then in 2016 , it declined again to $6.99 \%$. The NPF level which is classified as high and often fluctuating, of course, makes the return of financing that has been distributed by KJKS to customers very disturbed. The impact of this high and fluctuating NPF certainly reduces the efficiency of a financial institution. The analysis results for returning the questionnaire can be seen in the following table:

Table 4. Analysis Results Return Questionnaire

\begin{tabular}{lcc}
\hline \multicolumn{1}{c}{ Information } & Amount & Frequency \\
\hline Questionnaire distributed & 89 & $100 \%$ \\
\hline The questionnaire that did not return & $(4)$ & $(4.50 \%)$ \\
\hline Incomplete questionnaire & $(5)$ & $(5.62 \%)$ \\
\hline The questionnaire that can be analyzed & 80 & $(89.88 \%)$ \\
\hline Source: Processed by the author, 2017. & &
\end{tabular}

\section{Descriptive Analysis}

Based on the table (appendix) it can be concluded that the majority of respondents have a good intention to pay installment financing. This is evidenced by the high Respnden Achievement Level (TCR) value of the Religiosity variable which is equal to 3.90 and the agreed answers (S) of 54 votes $(67.5 \%)$. Most of the respondents carry out their obligations as Muslims namely to pray five times a day even though most only run at home, this is indicated by the respondents' agreed voice answers (S) of 61 votes (76.25\%) and TCR of 3.98. Prayer is done at home because the respondent is too busy when taking care of the business that is done 
so that it is difficult to carry out prayers or carry out other religious activities such as listening to religious teachings/prayers / religious lectures at the mosque. In the habit of paying off installments, most respondents answered, often paying late installments or not making timely installments, this was indicated by the disagreement (TS) of 28 votes $(35 \%)$ and a fairly low TCR of 3.21. For customers 'determination in paying off the financing, most respondents said they were able to pay off the financing they had done. This was indicated by the results of the respondents' answers agreeing (S) as many as 38 votes $(47.5 \%)$ and TCR which was quite high at 3.60 .

Based on table (Appendix) shows that KJKS customers in Padang City before obtaining financing are required to submit proposals that are used to explain what and how to use the funds they have received from KJKS this is evidenced by a high TCR of 3.69 and the results of respondents' answers agree (S) 41 votes (51.25\%). Most of the customers use these funding funds under the proposals they have submitted, this is evidenced by the answers of respondents agree (S) of 42 votes $(52.5 \%)$ and TCR which is quite high at 3.50. Usually, KJKS employees will assist customers in preparing these proposals, this is indicated by the majority of respondents' answers agreeing (S) as many as 24 votes (30\%) and TCR which is quite high at 3.48 .

However, funding is felt unable to meet the educational needs of respondents, this is proven by the disagreement (TS) of 29 votes (36.25\%) and TCR of 3.03. As for indicators of income capability to pay off their financing, most respondents answered that their income was sufficient to pay off the financing, this is evidenced by the agreed answers (S) of 38 votes $(47.5 \%)$ and TCR of 3.54 .

The initial requirements for financing are easy to understand, this is evidenced by the answers to strongly agree (SS) as many as 35 votes $(43.75 \%)$ and a high TCR value of 4.23 , in addition to being easily understood the initial requirements of the KJKS are also easily met. answers strongly agree (SS) as many as 35 votes (43.75\%) and TCR value of 4.23 , and also do not require a long time proven by agreeing answers (S) of 46 votes $(57.5 \%)$ and TCR value of 4.15 , and has installments that mild as evidenced by the agreeing answer (S) of 46 votes $(57.5 \%)$ and a TCR value of 4.18 for this reason that makes customers interested in using the financing offered by KJKS. In addition, most KJKS customers have ever done financing at the bank and rejected this is evidenced by the answers to the very agree (SS) this is indicated by the respondents' answers as many as 30 votes $(37.5 \%)$ and TCR value of 3.70 .

The majority of respondents felt that KJKS employees behaved friendly as evidenced by the 46 respondents agreeing strongly (SS) and a high TCR score of 4.56, being kind and polite showing with 45 agreeing answers (SS) 45 votes (56.25\%) and a TCR value of 4.53, being cooperative/willing to cooperate is indicated by a very agreeable answer (SS) of 37 votes and a TCR value of 4.31, the arrival of KJKS employees does not interfere with the customer's busyness as evidenced by the agreeing answer (S) 48 votes (60\%) and a TCR value of 4.11 , with the above reasons it can be concluded that the customer has a good relationship with KJKS employees is also evidenced by the results of the respondents' agreed answers (S) of 31 votes $(38.75 \%)$ and TCR of 3.78 and the customers were satisfied with the evaluation carried out by KJKS employees, this was evidenced by the results of the answers of respondents strongly agree (SS) as many as 44 votes (55\%) and a TCR value of 4.54 .

Based on the table shows the results that the first-factor causing problematic financing that occurred in KJKS Padang City was caused by financial difficulties, this was evidenced by the results of respondents' answers strongly agree (SS) as many as 27 votes (33.75\%) and TCR value which was quite high at 3.60, the second-factor causing problematic financing is prolonged illness experienced by customers, this is evidenced by the results of respondents' answers agree (S) as many as 9 votes $(11.25 \%)$ and the TCR value is quite low at 2.35 . The third-factor causing financing problems, namely the person in charge/backbone of the family 
died this is evidenced by the results of the respondents' answers agreeing to 4 votes (5\%) and a fairly low TCR value of 1.81. While the last factor causing problematic financing is divorce experienced by customers, this is evidenced by the results of respondents' answers strongly agree as many as 3 votes $(3.75 \%)$ with a TCR value of 1.89 .

\section{Hypothesis Testing}

Table 5

Determination Coefficient Test Results (Adjusted R2)

\begin{tabular}{lcccc}
\hline Model & $\mathrm{R}$ & R Square & Adjusted R Square & Std. Error \\
\hline 1 & 0.524 & 0.275 & 0.226 & 234,541 \\
\hline Source: Processed by the author, 2017.
\end{tabular}

The adjusted $\mathrm{R}^{2}$ value in the table is 0.226 . This shows that the magnitude of the ability of the independent variable, customer religiosity, financial planning, customer income, initial administration requirements, and evaluation by KJKS in explaining the dependent variable, i.e. problematic financing is equal to $22.6 \%$. While $77.4 \%$ is determined by other variables outside the model research.

Table 6. Test Results t

\begin{tabular}{ccc}
\hline Model & T & Sig. \\
\hline Constant & 6,794 & 0 \\
\hline RNT & $-3,358$ & 0.001 \\
\hline PPT & -0.275 & 0.784 \\
\hline PNT & $-2,636$ & 0.01 \\
\hline APAT & $-1,868$ & 0.066 \\
\hline EPKT & $-1,955$ & 0.054 \\
\hline
\end{tabular}

Then get the following results:

1) Variable Factors of Customer Religiosity

The results obtained stated the value of Sig. $0.001<0.05$ so $\mathrm{H}_{0}$ is rejected and $\mathrm{H}_{1}$ is accepted. This means that the regression coefficient on customer religiosity factors significantly influences problem financing.

2) Variable Funding Planning Factors

The results obtained stated the value of Sig. $0.784>0.05$ so $\mathrm{H}_{0}$ is accepted. This means that the regression coefficient on the financing planning factor does not affect problem financing.

3) Customer Income Factor Variable

The results obtained stated the value of Sig. $0.010<0.05$ so $\mathrm{H}_{0}$ is rejected and $\mathrm{H}_{3}$ is accepted. This means that the regression coefficient on customer income factors significantly influences problem financing.

4) Variable Administrative Factors Initial Requirements

The results obtained stated the value of Sig. 0.066> 0.05 so $\mathrm{H}_{0}$ is accepted. This means that the regression coefficient on the initial requirements administration factor does not affect the problematic financing.

5) Evaluation Factor Variables by KJKS

The results obtained stated the value of Sig. 0.054> 0.05 so $\mathrm{H}_{0}$ is accepted. This means that the regression coefficient on the evaluation factor by the KJKS does not affect the problematic financing.

Results of the F test between all independent variables with the dependent variable, which shows the value of Sig. of 0,000 . This means that the significance value is smaller than alpha $0.05(0.000<0.05)$, so it can be concluded that customer religiosity, financial planning, 
customer income, initial administration requirements, and evaluation by the KJKS have a joint effect on problem financing seen from customer perspective on KJKS in Padang City.

Table 7. Test Results F

\begin{tabular}{cccccc}
\hline Model & Sum of Square & DF & Mean Square & F & Sig. \\
\hline Regression & 154,480 & 5 & 30,896 & 5,617 & 0,000 \\
\hline Residual & 407,070 & 74 & 5,501 & & \\
\hline Total & 561,550 & 79 & & & \\
\hline Soun
\end{tabular}

Source: Processed by the author, 2017.

\section{Discussion}

Variable factors of customer religiosity the results obtained stated the value of Sig. 0.001 $<0.05$ so $\mathrm{H}_{0}$ is rejected and $\mathrm{Ha}$ is accepted. This means that the regression coefficient on customer religiosity factors significantly influences problem financing. Variable funding planning factors the results obtained stated the value of Sig. $0.784>0.05$ so $\mathrm{H}_{0}$ is accepted. This means that the regression coefficient on the financing planning factor does not affect problem financing. Customer income factor variable the results obtained stated the value of Sig. 0.010 $<0.05$ so $\mathrm{H}_{0}$ is rejected and $\mathrm{Ha}$ is accepted. This means that the regression coefficient on customer income factors significantly influences problem financing. Variable administrative factors initial requirements the results obtained stated the value of Sig. $0.066>0.05$ so $\mathrm{H}_{0}$ is accepted. This means that the regression coefficient on the initial requirements administration factor does not affect the problematic financing. Evaluation factor variables by KJKS the results obtained stated the value of Sig. 0.054> 0.05 so $\mathrm{H}_{0}$ is accepted. This means that the regression coefficient on the evaluation factor by the KJKS does not affect the problematic financing. In this part independent variable, customer religiosity, financial planning, customer income, initial administration requirements, and evaluation by KJKS in explaining the dependent variable, i.e. problematic financing is equal to $22.6 \%$. While $77.4 \%$ is determined by other variables outside the model research. Results of the $\mathrm{F}$ test concluded that customer religiosity, financial planning, customer income, initial administration requirements, and evaluation affect KJKS.

\section{Conclusions}

Customer Religiosity significant effect on NPF. Financing Planning no effect on NPF. Customer Revenuesignificant effect on NPF. Initial Administration Requirements no effect on NPF. Evaluation by KJKS does not affect NPF.

\section{BIBLIOGRAPHY}

Abdulkader, e. a. (2013). Islamic vs Conventional Microfinance Institutions: Performance Analysis in MENA Countries. International Journal of Business and Social Research (IJBSR), (3) 5: 219-233.

Ayuningtiyas, A. (2012). Analysis of Factors Affecting Bad Credit in Sharia Microfinance Institutions Baitul Maal Wa Tamwil Kube Colomadu Year 2010-2011. Faculty of Teacher Training and Education, Muhammadiyah University, Surakarta., Surakarta.

Dendawijaya, L. (2005). Banking Management. .Jakarta : Ghalia Indonesia.

Harmoyo, D. (2012). Strategic Management of Sharia Microfinance Services (KJKS) Case Study in Baitul Mal Wat Tamwil (BMT) Syariah Sejahtera Boyolali. Unpublished Paper. BMT Syariah Sejahtera Boyolali, Muqtasid Journal. 
Husni, T. (2016).Sharia Microfinance Institution Model Development with Data Development Analysis Approach, Poverty Reduction Outreach, Financial Sustainability, and Social Capital Performance. Economic Journals. Padang: Andalas University.

infobanknews.com. 2017. [diakses pada.

Kepmen, k. N. M. K. I. 2004. [diakses pada.

Law, N. o. R. 1998. concerning Amendments to Law No. 7 of 1992 concerning Banking.

Listanti, D., et al (2015). Troubled Murabahah Financing Efforts at Sharia Financial Institutions (Study on KJKS Baitul Maal Wat Tamwil (BMT) Mandiri Sejahtera Karangcangkring Gresik, East Java Period 2011-2013). Journals. Malang: Faculty of Administrative Sciences Brawijaya University.

Marantika, C. R. (2013). Analysis of Factors Influencing Micro Micro Business Credit (KUR) Smoothness (Case Study at PT Bank BRI (Persero) Tbk. Tawangsari II Unit, Sukoharjo Branch 2013)", Faculty of Economics and Business, Diponegoro University.s, Diponegoro University.

Maulidia, A. a. N. A. (2016).Analysis of Sharia Cooperative Compliance with Sharia Principles based on Permen K.UMKM Number: 35.3 / Per / M.KUMKM / X / 2007. Student Scientific Journal of the Faculty of Business Economics, (5) 2.

Novitasari, M. R. (2010). Factors Affecting Bad Credit Risk in the Islamic Financial Services Cooperative "Amanah Ummah" Surabaya. Thesis. Surabaya: Faculty of Social and Political Sciences, East Java "Veteran" National Development University.

Popita, A. (2013). "Analysis of the Causes of Non Performing Financing in Islamic Commercial Banks in Indonesia.". Accounting Analysis Journal (7) 2.

Siregar, S. April (2013). Character of Sharia Bank Debtors in Meeting Obligations.". TSAQAFAH Journal,(9) 1.

Siswandi, E. (2004). Measuring the Relative Efficiency of Bank Branch Offices Using Data Envelopment Analysis (DEA). Indonesian Entrepreneur Management Journal, (33) 01.

Weber, M. (1905). The Protestant Ethic and the Spirit of Capitalism. . German.

Wijayanti, P. S. (2014). Analysis of Factors Affecting Bad Credit in Sharia Microfinance Institutions BMT Surya Madani Boyolali Year 2013-2014. Unpublished Paper. Muhammadyah University, Surakarta.,

Wira, V. a. G. (2015). Efforts to Strengthen Sharia Financial Services Cooperatives in the Framework of Empowering Community Commodities in Padang City. SNEMA Faculty of Economics, Padang State University : 47-54.

www.bi.go.id/. accessed February 5, 2017. [diakses pada.

Yuliana, D. (2016). Analysis of Factors That Influence Revolving Non-performing Loans in PNPM Mandiri in Rural Sub-districts of Guntur, Demak Regency. Journal of STIE Semarang, (8) 3. 